\title{
Quality Analysis and Characterization of Panchagavya, Jeevumrutha and Sasyamrutha
}

\author{
Bishal Chakraborty* and Indrajit Sarkar
}

Uttar Banga Krishi Viswavidyalaya, Coochbehar-736165, West Bengal, India

*Corresponding author

Keywords

Panchagavya, Jeevumrutha, Sayamrutha and Liquid Organic manure

Article Info

Accepted:

17 April 2019

Available Online:

10 May 2019
A study on quality analysis and characterization of Panchagavya, Jeevumrutha and Sasyamrutha was carried out in the departments of soil science, plant pathology and biochemistry, UBKV, coochbehar-736165, West Bengal during February, 2019. Motive of this work was to characterize these liquid organic manures according to their Physical properties, macro and micro nutrient Content, Microbial population and amount of growth promoters present in them. Jeevumrutha recorded highest values in most of the parameters followed by Panchagavya and Sasyamrutha. It is recommended that all of these liquid organic manures can be used as an alternative against chemical fertilizers and pesticides.

\section{Introduction}

Excessive use of chemical fertilizers and pesticides deteriorates the soil quality by changing the physical, chemical and biological properties of soil. They adversely affect the microbial population present in the soil and due to that ecological balance is hampered. Now-a-days liquid organic manures are becoming popular to combat the adverse effect of chemical fertilizers. They can supply essential nutrients to the crop plant and also provide several growth promoters and bio-control agents to prevent disease and pest infestation. Liquid organic manures can be prepared by using several farm inputs and daily household materials. So the cost required to prepare these liquid organic manures are very less comparing with the chemical fertilizers and pesticides. In order to maintain sustainability in agriculture liquid organic manures should be adopted in a large extent (Kannaiyan, 2000; Kanwar, 2006). Panchagavya literally means "mixture of five cow products". According to Hindu dharma, Panchagavya has high significance. It can be used as an Ayurvedic medicine and it has good potential as an organic fertilizer and pesticide (Dhama et al., 2005; Kumar, 2005). Jeevumrutha is one of the four pillars of the 
Zero Budget Natural Farming (ZBNF). As the name signifies, Jeevumrutha is highly cost effective for the farmers (FAO, 2016). Sasyamrutha is fermented liquid organic manure having different types of leaves with cow dung and cow urine. It has nutritional and bio-control properties for the crop plants (Green Foundation, 2009). All of them have significant nutrient content, beneficial microbial population load, growth promoters and bio-control agents. To popularize the use of Panchagavya, Jeevumrutha and Sasyamrutha, scientific validation of these manures is highly required. With this motive I decided to investigate the quality parameters of Panchagavya, Jeevumrutha and Sasyamrutha for their scientific characterization.

\section{Materials and Methods}

Methodologies of preparation of Panchagavya, Jeevumrutha and Sasyamrutha with their ingredients are described below.

\section{Preparation of panchagavya}

\section{Ingredients}

Jersey cow dung $(3.5 \mathrm{Kg})$, Jersey cow urine (5 litres), Jersey cow milk (1.5 litres), Curd (1 litres), Jaggery $(1.5 \mathrm{Kg})$, Ghee $(0.5 \mathrm{Kg})$, Banana (6 numbers), Tender coconut (1.5 litres) and Water (5 litres).

\section{Procedure}

All of the above materials should be mixed in an earthen pot according to their proportion, keep it in shady place and close the container. Then stir the mixture twice a day in both the directions. After 30 days the solution is prepared and it should be filtered and collected (Sarkar et al., 2011).

\section{Preparation of Jeevumrutha}

\section{Ingredients}

Water (8-10 litres), Jersey cow dung (0.4-0.6 $\mathrm{kg})$, Jersey cow urine (0.12-0.16 litres) and Jaggery $(0.04-0.08 \mathrm{~kg})$.

\section{Procedure}

Mix all of them and keep them in a shade for 3-4 days. Stir the mixture once a day. After 20 days the mixture should be filtered and has to be collected (Shankaran, 2009).

\section{Preparation of Sasyamrutha}

\section{Ingredients}

Jersey cow dung $(5 \mathrm{~kg})$, Jatropha leaves $(0.6$ $\mathrm{kg})$, Datura leaves $(0.6 \mathrm{~kg})$, Jersey Cow urine (0.6 litres), Mustard oil cake (0.4 kg), Jaggery $(0.2 \mathrm{~kg})$, Ash of Agnihotra $(0.1 \mathrm{~kg})$ and Water (40 litres).

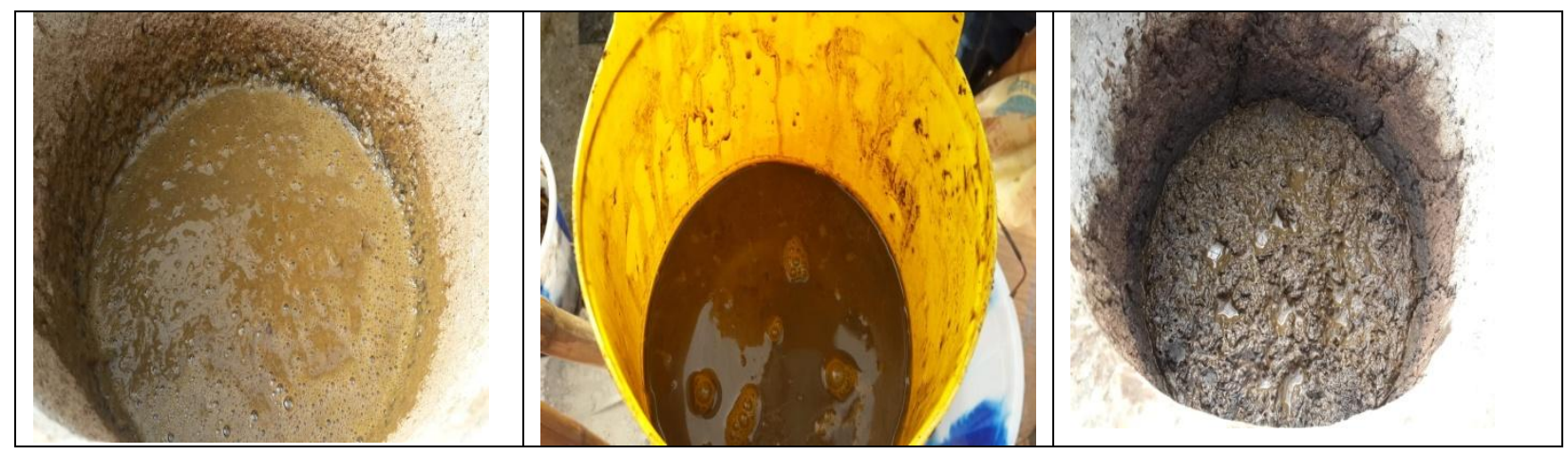




\section{Procedure}

Chopped jatropha and datura leaves must be kept in the container. Then add water, cow dung, cow urine, oil cake, agnihotra ash and jaggery on it with above mentioned proportion. After that stir it well and close the container. Daily stirring for aeration should be done. After 20 days the fermented mixture must be filtered and Sasyamrutha has to be collected (Green Foundation, 2009).

\section{Panchagavya Jeevumrutha Sasyamrutha}

\section{Characterization of Panchagavya,} Jeevumrutha and Sasyamrutha

The physical, chemical, biochemical and biological properties of Panchagavya, Jeevumrutha, and Sasyamrutha were analysed to estimate their constituents using standard procedures. The standard procedures followed for estimation of various properties of these solutions are given in Table 1 to 2 .

\section{Results and Discussion}

The physical and physico-chemical properties of Panchagavya, Jeevumrutha and Sasyamrutha are presented in Table 3.

The colour of freshly prepared Panchagavya was light brown and as the storage period increased, the preparation became darker in colour. It might be due to a series of nonenzymatic Maillard's reactions, started with binding of aldehyde group of lactose with $\varepsilon$ amino group of the lysyl - residues (aminoacid radical, or residue of amino-acid lysine) from different milk proteins during storage. These reactions caused the formation of brown-coloured pigments, such as pyralysins and melanoidins, polymers such as lactuloselysine or fructose-lysine, as well as lowmolecular weight acids. Cow dung and cow urine enhanced the rate of decomposition and for that dark brown colour was developed (Kneifel et al., 1992) (Singh et al., 1992). Fresh preparation of Panchagavya possessed a fruity smell. Foul odour was observed after 20 days and progressed up to the end of storage. The reason behind this might be the light sensitiveness of riboflavin and riboflavin absorbed visible and ultra violet light, converting that energy into highly reactive forms of oxygen. That induced a whole series of oxidative reactions, caused oxidation of fat. For that undesirable foul odours was formed (Min, 2002; Borle, 2001).

Fresh preparation of Jeevamrutha was moderate green in colour and with time the colour became darker. Jeevamrutha had mild odour in fresh preparation; it gradually increased after 20 days and was constant till the end of the storage period. The reason behind these might be the presence of jaggary. Presence of water with jaggery promoted growth of microbes and for that decomposition of cow dung was enhanced in Jeevumrutha. Due to that dark green colour and mild foul odour was produced (Ravindra et al., 2016).

Freshly prepared Sasyamrutha was green in colour and it became dark green till the end of storage period. Fresh preparation of Sasyamrutha possessed a leafy smell but after 10 days mild foul odour was produced. Soaking of mustard cake in water induced the endogenous 'Myrosinase' enzyme and that react with glucosinolate resulting in substantial hydrolysis of glucosinolate to volatile metabolites viz. isothiocyanate, CNS, nitriles and other degradation products and decomposition of plant materials produce carbon dioxide. Due to that the change in colour and foul smell after during decomposition was noticed (Tyagi et al., 1997; Chu and Jennifer, 2018). Jeevumrutha recorded highest $\mathrm{pH}$ (8.24) followed by Sasyamrutha (8.05) and Panchagavya (5.32). 
Among them Panchagavya recorded highest EC $(11.02 \mathrm{dS} / \mathrm{m})$ followed by Sasyamrutha $(6.56 \mathrm{dS} / \mathrm{m})$ and Jeevumrutha $(1.44 \mathrm{dS} / \mathrm{m})$. Highest organic carbon (OC) value was found in Panchagavya $(0.861 \%)$ followed by Sasyamrutha $(0.247 \%)$ and Jeevumrutha $(0.094 \%)$

Pathak and Ram (2013) also found low pH in Panchagavya due to production of several organic acids in it during fermentation. Alcohol (methanol, propanol, butanol and ethanol) production in Jeevumrutha as a byproduct of fermentation made it alkaline in nature (Natarajan, 2008). Sasyamrutha was alkaline in nature might be due to release of carbon dioxide and other volatile metabolites like isothiocyanate, CNS, nitriles and other degradation products (Tyagi et al., 1997; Chu and Jennifer, 2018).

The macro and micro nutrient content of Panchagavya, Jeevumrutha and Sasyamrutha are presented in Table 4. Panchagavya had highest content of $\mathrm{N}$ (2366 ppm) followed by Sasyamrutha (742 ppm) and Jeevumrutha (658 ppm). Highest content of $\mathrm{P}$ was recorded in Jeevumrutha (195 ppm) followed by Panchagavya (187 ppm) and Sasyamrutha (96 ppm). K content was highest in Panchagavya (1354 ppm) followed by Jeevumrutha (821 ppm) and Sasyamrutha (323 ppm). Highest content of Ca was found in Sasyamrutha (194 $\mathrm{mg} / \mathrm{l})$ followed by Jeevumrutha $(189 \mathrm{mg} / \mathrm{l})$ and Panchagavya (152 mg/l). Panchagavya had highest content of $\mathrm{Mg}$ (48 mg/l) followed by Sasyamrutha $(34 \mathrm{mg} / \mathrm{l})$ and Jeevumrutha (19 $\mathrm{mg} / \mathrm{l})$. $\mathrm{S}$ content was highest in Jeevumrutha $(564 \mathrm{mg} / \mathrm{l})$ followed by Sasyamrutha $(503 \mathrm{mg} / \mathrm{l})$ and Panchagavya (485 mg/l). Highest Fe content was noticed in Jeevumrutha $(42.44 \mathrm{mg} / \mathrm{l})$ followed by Sasyamrutha $(14.47 \mathrm{mg} / \mathrm{l})$ and Panchagavya (9.17 mg/l), Jeevumrutha had highest content of Mn $(0.394 \mathrm{mg} / \mathrm{l})$, followed by Panchagavya $(0.287 \mathrm{mg} / \mathrm{l})$ and Sasyamrutha $(0.238 \mathrm{mg} / \mathrm{l})$.
Highest amount of $\mathrm{Zn}$ was found in Jeevumrutha $(1.56 \mathrm{mg} / \mathrm{l})$ followed by Panchagavya $(0.268 \mathrm{mg} / \mathrm{l})$ and Sasyamrutha $(0.249 \mathrm{mg} / \mathrm{l}) . \mathrm{Cu}$ content was highest in Jeevumrutha $(2.44 \mathrm{mg} / \mathrm{l})$ followed by Sasyamrutha $(2.36 \mathrm{mg} / \mathrm{l})$ and Panchagavya (2.18 mg/l). Dhanoji et al., (2018) and Parvathi and Ushakumari (2017) also recorded N, P, K, Ca, Mg, S, Fe, Mn, Zn, And $\mathrm{Cu}$ in Panchagavya and Jeevumrutha.

The microbial population of Panchagavya, Jeevumrutha and Sasyamrutha are given in Table 5. For bacterial count, highest value was noticed in Jeevumrutha $\left(14 \times 10^{5} \mathrm{cfu} / \mathrm{ml}\right)$ followed by Panchagavya $\left(12 \times 10^{4} \mathrm{cfu} / \mathrm{ml}\right)$ and Sasyamrutha $\left(9 \times 10^{4} \mathrm{cfu} / \mathrm{ml}\right)$. Highest fungi count found in Jeevumrutha $\left(17 \times 10^{3}\right)$ followed by Sasyamrutha $\left(13 \times 10^{3}\right)$ and Panchagavya $\left(9 \times 10^{3}\right)$. Highest value of Actinomycetes was found in Panchagavya (4 $\left.\mathrm{x} 10^{3} \mathrm{cfu} / \mathrm{ml}\right)$ followed by Jeevumrutha $(2 \mathrm{x}$ $\left.10^{3} \mathrm{cfu} / \mathrm{ml}\right)$ and Sasyamrutha $\left(6 \times 10^{2} \mathrm{cfu} / \mathrm{ml}\right)$. $E$ coli was highest in Panchagavya $\left(9 \times 10^{5}\right.$ $\mathrm{cfu} / \mathrm{ml})$ followed by Sasyamrutha $\left(12 \times 10^{3}\right.$ $\mathrm{cfu} / \mathrm{ml})$ and Jeevumrutha $\left(5 \times 10^{2} \mathrm{cfu} / \mathrm{ml}\right)$. Highest count of Azospirilum was found in Jeevumrutha $\left(8 \times 10^{3} \mathrm{cfu} / \mathrm{ml}\right)$ followed by Sasyamrutha (3 $\quad$ x $\left.10^{2} \quad \mathrm{cfu} / \mathrm{ml}\right)$ and Panchagavya $\left(2 \times 10^{2} \mathrm{cfu} / \mathrm{ml}\right)$. Jeevumrutha had highest Azotobacter count $\left(15 \times 10^{6}\right.$ $\mathrm{cfu} / \mathrm{ml})$ followed by Sasyamrutha $\left(10 \times 10^{4}\right.$ $\mathrm{cfu} / \mathrm{ml})$ and Panchagavya $\left(2 \times 10^{4} \mathrm{cfu} / \mathrm{ml}\right)$. P solubilizers were highest in Sasyamrutha (14 x $\left.10^{5} \mathrm{cfu} / \mathrm{ml}\right)$ followed by Panchagavya $(9 \mathrm{x}$ $\left.10^{5} \mathrm{cfu} / \mathrm{ml}\right)$ and Jeevumrutha $\left(3 \times 10^{4} \mathrm{cfu} / \mathrm{ml}\right)$. $\mathrm{K}$ solubilizers were absent in Jeevumrutha, they are highest in Panchagavya $\left(4 \times 10^{3}\right.$ $\mathrm{cfu} / \mathrm{ml})$ followed by Sasyamrutha $\left(4 \times 10^{2}\right.$ $\mathrm{cfu} / \mathrm{ml})$. Pseudomonas population was highest in Jeevumrutha $\left(11 \times 10^{5} \mathrm{cfu} / \mathrm{ml}\right)$ followed by Panchagavya (6 $\left.60^{5} \quad \mathrm{cfu} / \mathrm{ml}\right)$ and Sasyamrutha (5 x $\left.10^{5} \mathrm{cfu} / \mathrm{ml}\right)$. Rhizobium population was highest in Jeevumrutha (7 $\mathrm{x}$ $\left.10^{6} \mathrm{cfu} / \mathrm{ml}\right)$ followed by Sasyamrutha $\left(8 \times 10^{4}\right.$ $\mathrm{cfu} / \mathrm{ml})$ and Panchagavya $\left(6 \times 10^{4} \mathrm{cfu} / \mathrm{ml}\right)$. 
Ram et al., (2017) and Parvathi and Ushakumari (2017) also noticed bacteria, fungi, Actinomycetes, Pseudomonas, $\mathrm{P}$ solubilising microbes, $\mathrm{K}$ solubilising microbes, E. coli, Rhizobium, Azotobacter and Azospirilum in Panchagavya and Jeevumrutha.

Table.1 Physical and chemical properties of Panchagavya, Jeevumrutha and Sasyamrutha

\begin{tabular}{|c|c|c|c|}
\hline Sl. No. & Parameters & Methods & Reference \\
\hline 1 & Colour & Visual evaluation & \\
\hline 2 & Odour & Sensory evaluation & \\
\hline 3 & $\mathrm{pH}$ & pH meter method & Jackson (1973) \\
\hline 4 & $\mathrm{EC}$ & Conductivity meter method & Jackson (1973) \\
\hline 5 & Organic carbon & Walkley and Black wet digestion & $\begin{array}{l}\text { Walkley and Black } \\
\text { (1934) }\end{array}$ \\
\hline 6 & Total Nitrogen & Microkjeldhal method & Jackson (1973) \\
\hline 7 & Total Phosphorus & $\begin{array}{l}\text { Nitric-Perchloric (9:4) digestion and colorimetry } \\
\text { using vanado-molybdo phosphoric yellow colour } \\
\text { method }\end{array}$ & Jackson (1973) \\
\hline 28 & Total Potassium & $\begin{array}{l}\text { Nitric-perchloric (9:4) digestion and flame } \\
\text { photometry }\end{array}$ & Jackson (1973) \\
\hline 9 & Total Calcium & Nitric-perchloric (9:4) digestion and AAS & Jackson (1973) \\
\hline 10 & Total Magnesium & Nitric-perchloric (9:4) digestion and AAS & Jackson (1973) \\
\hline 11 & Total Sulphur & Nitric-perchloric (9:4) digestion and Turbidimetry & $\begin{array}{l}\text { Massoumi } \\
\text { Cornfield(1963) }\end{array}$ \\
\hline 12 & $\begin{array}{l}\text { Total Micronutrients } \\
\mathrm{Fe}, \mathrm{Mn}, \mathrm{Zn}, \mathrm{Cu}\end{array}$ & Nitric-perchloric(9:4) digestion and AAS & Jackson (1973) \\
\hline
\end{tabular}

Table.2 Biochemical and biological properties of Panchagavya, Jeevumrutha and Sasyamrutha

\begin{tabular}{|l|l|l|l|}
\hline SI. No. & Parameters & Methods & Reference \\
\hline $\mathbf{1}$ & Ascorbic Acid content & Titrimetric method & Sadasivram and Manickam (1996) \\
\hline $\mathbf{2}$ & Indole Acetic Acid & Spectrophotometric method & Ahmad et al., (2005) \\
\hline $\mathbf{3}$ & Gibberelic Acid & Spectrophotometric method & Cho et al., (1979) \\
\hline $\mathbf{4}$ & Cytokinin & Bioassay & Letham (1971) \\
\hline $\mathbf{5}$ & Bacteria & Nutrient Agar medium & Atlas and Parks (1993) \\
\hline $\mathbf{6}$ & Fungi & Martin's rose Bengal Agar & Martin (1950) \\
\hline $\mathbf{7}$ & Actinomycetes & Ken knight's Agar medium & Cappuccino and Sheman (1996) \\
\hline $\mathbf{8}$ & E.coli & Eosin methylene blue & Levine (1918) \\
\hline $\mathbf{9}$ & Azospirilum & Nitrogen free Bromothymol blue medium & Dobereiner et al.,(1976) \\
\hline $\mathbf{1 0}$ & Azotobacter & Jensen's medium & Jensen (1942) \\
\hline $\mathbf{1 1}$ & P solubilizers & Pikovskaya's mediam & Sundaran and Sinha (1963) \\
\hline $\mathbf{1 2}$ & K solubilizers & Aleksandrov Agar medium & Sugumara and Janartham (2007) \\
\hline $\mathbf{1 3}$ & Pseudomonas sp. & King's B Agar medium & King et al., (1954) \\
\hline $\mathbf{1 4}$ & Rhizobium & $\begin{array}{l}\text { Yeast extract Mannitol Agar with Congo } \\
\text { red }\end{array}$ & Fred et al., (1932) \\
\hline
\end{tabular}


Table.3 Physical and physic-chemical parameters of Panchagavya, Jeevumrutha and Sasyamrutha

\begin{tabular}{|l|l|l|l|}
\hline Parameters & Panchagavya & Jeevumrutha & Sasyamutha \\
\hline Colour & Light brown & Moderate green & Green \\
\hline Odour & Fruity smell & Mild foul smell & Leafy \\
\hline pH & 5.32 & 8.24 & 8.05 \\
\hline EC $(\mathbf{d S} / \mathbf{m})$ & 11.02 & 1.44 & 6.56 \\
\hline OC $(\mathbf{\%})$ & 0.861 & 0.098 & 0.247 \\
\hline
\end{tabular}

Table.4 Macro and micro nutrient content of Panchagavya, Jeevumrutha and Sasyamrutha

\begin{tabular}{|l|l|l|l|}
\hline Parameters & Panchagavya & Jeevumrutha & Sasyamrutha \\
\hline $\mathbf{N}(\mathbf{p p m})$ & 2366 & 658 & 742 \\
\hline $\mathbf{P}(\mathbf{p p m})$ & 187 & 195 & 96 \\
\hline $\mathbf{K}(\mathbf{p p m})$ & 1354 & 821 & 323 \\
\hline $\mathbf{C a}(\mathbf{m g} / \mathbf{l})$ & 152 & 189 & 194 \\
\hline $\mathbf{M g}(\mathbf{m g} / \mathbf{l})$ & 48 & 19 & 34 \\
\hline $\mathbf{S}(\mathbf{m g} / \mathbf{l})$ & 485 & 564 & 503 \\
\hline $\mathbf{F e}(\mathbf{m g} / \mathbf{l})$ & 9.17 & 42.44 & 14.47 \\
\hline $\mathbf{M n}(\mathbf{m g} / \mathbf{l})$ & 0.287 & 0.394 & 0.238 \\
\hline $\mathbf{Z n}(\mathbf{m g} / \mathbf{l})$ & 0.268 & 1.56 & 0.249 \\
\hline $\mathbf{C u}(\mathbf{m g} / \mathbf{l})$ & 2.18 & 2.44 & 2.36 \\
\hline
\end{tabular}

Table.5 Microbial population of Panchagavya, Jeevumrutha and Sasyamrutha

\begin{tabular}{|l|l|l|l|}
\hline Parameters & Panchagavya & Jeevumrutha & Sasyamrutha \\
\hline Bacteria $(\mathbf{c f u} / \mathbf{m l})$ & $12 \times 10^{4}$ & $14 \times 10^{5}$ & $9 \times 10^{4}$ \\
\hline Fungi $(\mathbf{c f u} / \mathbf{m l})$ & $9 \times 10^{3}$ & $17 \times 10^{3}$ & $13 \times 10^{3}$ \\
\hline Actinomycetes $(\mathbf{c f u} / \mathbf{m l})$ & $4 \times 10^{3}$ & $2 \times 10^{3}$ & $6 \times 10^{2}$ \\
\hline E.coli $(\mathbf{c f u} / \mathbf{m l})$ & $9 \times 10^{5}$ & $5 \times 10^{2}$ & $12 \times 10^{3}$ \\
\hline Azospirilum $(\mathbf{c f u} / \mathbf{m l})$ & $2 \times 10^{2}$ & $8 \times 10^{3}$ & $3 \times 10^{2}$ \\
\hline Azotobacter $(\mathbf{c f u} / \mathbf{m l})$ & $2 \times 10^{4}$ & $15 \times 10^{6}$ & $10 \times 10^{4}$ \\
\hline P solubilizers $(\mathbf{c f u} / \mathbf{m l})$ & $9 \times 10^{5}$ & $3 \times 10^{4}$ & $14 \times 10^{5}$ \\
\hline K solubilizers $(\mathbf{c f u} / \mathbf{m l})$ & $4 \times 10^{3}$ & 0 & $4 \times 10^{2}$ \\
\hline Pseudomonus $(\mathbf{c f u} / \mathbf{m l})$ & $6 \times 10^{5}$ & $11 \times 10^{5}$ & $5 \times 10^{5}$ \\
\hline Rhizobium $(\mathbf{c f u} / \mathbf{m l})$ & $6 \times 10^{4}$ & $7 \times 10^{6}$ & $8 \times 10^{4}$ \\
\hline
\end{tabular}

Table.6 Biochemical parameters of Panchagavya, Jeevumrutha and Sasyamrutha

\begin{tabular}{|l|l|l|l|}
\hline Parameters & Panchagavya & Jeevumrutha & Sasyamrutha \\
\hline IAA $(\boldsymbol{\mu g} / \mathbf{m l})$ & 4.45 & 6.02 & 3.87 \\
\hline GA $(\boldsymbol{\mu g} / \mathbf{m l})$ & 26.76 & 36.22 & 30.00 \\
\hline Cytokinin $(\boldsymbol{\mu g} \mathbf{g} \mathbf{m l})$ & 3.12 & 2.86 & 2.48 \\
\hline AscorbicAcid $(\boldsymbol{\mu g} / \mathbf{m l})$ & 13.00 & 12.94 & 16.24 \\
\hline
\end{tabular}


The biochemical constituents of Panchagavya, Jeevumrutha and Sasyamrutha are written in Table 6. Jeevumrutha recorded highest value of IAA $(6.02 \mu \mathrm{g} / \mathrm{ml})$ followed by Panchagavya $(4.45 \mu \mathrm{g} / \mathrm{ml})$ and Sasyamrutha $(3.87 \mu \mathrm{g} / \mathrm{ml})$. Highest amount of GA was recorded in Jeevumrutha $(36.22 \mu \mathrm{g} / \mathrm{ml})$, followed by Sasyamrutha $(30.00 \mu \mathrm{g} / \mathrm{ml})$ and Panchagavya $\quad(26.76 \mu \mathrm{g} / \mathrm{ml})$. Cytokinin content was highest in Panchagavya (3.12 $\mu \mathrm{g} / \mathrm{ml})$ followed by Jeevumrutha $(2.86 \mu \mathrm{g} / \mathrm{ml})$ and Sasyamrutha $(2.48 \mu \mathrm{g} / \mathrm{ml})$. Ascorbic acid was highest in Sasyamrutha (16.24) followed by Panchagavya $(13.00 \mu \mathrm{g} / \mathrm{ml})$ and Jeevumrutha $(12.94 \mu \mathrm{g} / \mathrm{ml})$. Parvathi and Ushakumari (2017), Dhanoji et al., (2018) also observed IAA, GA, Cytokinin and Ascorbic Acid in Panchagava and Jeevumrutha.

The study concludes that Panchagavya, Jeevumrutha and Sasyamrutha have good potential as manure to improve the physical, chemical and biological properties of soil. This will directly help to increase the productivity of soil in long run and produce chemical residue free healthy crops. The ingredients needed to prepare these organic solutions are highly available and require very less investment. So using them instead of chemical fertilizers and pesticides are highly cost effective for the farmers. Among these organic solutions Jeevumrutha recorded highest values in most of the parameters. Proper use of these solutions in crop field will definitely increase the crop yield by supplying all the essential nutrients, growth promoters and bio-control agents.

\section{Acknowledgement}

I express my gratitude to Dr. Sekhar Bandhopadhyay, Associate Professor, Dept. of Plant Pathology, Dr. Abhas Kumar Sinha, Associate Professor, Dept. of Soil Science and Agricultural Chemistry, UBKV,
Coochbehar, West Bengal for their help and guidance during the period of analysis. My special thanks to Saddam da, Salim da, Amar $\mathrm{da}$, for their cooperation during laboratory work.

\section{References}

Ahmad, F., Ahmad,I. and Khan, M.S. 2005. Indole acetic acid production by indigenous isolates of Azotobacter and fluorescent Pseudomonas in the presence and absence of tryptophan. Turkish Journal of Biology, vol. 29, pp. 29-34.

Atlas, R. M. and Parks, L. C. 1993. Handbook of microbiological media, CRC Press, Inc. London, 529p.

Borle, F., Sieber, R. and Bosset, J. O. 2001. Photo-oxidation and photoprotection of foods with particular reference to dairy products: An update of review article (1993-2000) Sci. Aliments. 21:571-590.

Broadbent, F. E., Hill, G, N. and Tyler, K. B. 1964. Transformation and movement of urea in soils. Soil Sci. Soc. Am. Proc. 22: 303-307.

Cappuccino and Sheman. 1996. Microbiology - A laboratory manual (4th edn.), The Benjamin/ Cummings Publishing Company Inc., 213p.

Cho, K.Y., Sakurai, A and Kamiya, Y. 1979. Effects of the new plant growth retardants of quaternary ammonium iodides on gibberellin biosynthesis in Gibberella fujikuroi. Plant Cell Physiol. 20: 25- 81.

Chu and Jennifer. 2018. "MIT News". The mathematics of leaf decay. MIT News Office.

Dhama, K., Rathore, R., Chauhan, R. S. and Tomar, S. 2005. Panchagavya (Cowpathy): An Overview. International Journal of Cow Science, 1(1): 1-15.

Dhanoji, M. M., Meena, M. K. and Naik, M. 
C. 2018. Manure and plant extracts for foliar nutrition in organic farming: A Review. Int. Journal of Chem. Studies, 6(6)1447-1454.

Dobereiner, J., Marriel, I. E. and Nery, M. 1976. Ecological distribution of Spirillum lipoferum, Beijerinck. Can. J. Microbiol., 22: 1464- 1473.

Food and Agricultural Organization of United Nations., 2016. Zero Budget Natural Farming. Agro-ecology knowledge hub.

Fred, E. B, Baldwin, I. L. and McCoy, F. 1932. Root Nodule Bacteria and Leguminous Plants. University of Wisconsin Press, Madison, Wisconsin.

Green Foundation, Bangalore., 2009. Sustainable Agricultural Practices. III(9), pp-48. www.greenconserve.com.

Jackson, M. L. 1973. Soil Chemical Analysis. Prentice Hall of India Pvt. Ltd, New Delhi, pp.498.

Jensen, H. L. 1942. Nitrogen fixation in leguminous plants. General characteristics of root nodule bacteria isolated from species of Medicago and Trifolium in Australia. Proc. Linn. Soc. N.S.W. 66:98-108.

Kannaiyan, K., 2000. Biofertilizers: Key Factors in Organic Farming. The Hind Survey of Indian International Journal of Modern Plant and Animal Sciences, 1(2): 82-95.

Kanwar, K. S. S., Paliyal, Bedi, and Kaur, M., 2006. Integrated management of green manure, compost and nitrogen fertilizer in a rice-wheat cropping sequence. Crop Res., 31(3): 196-200.

King, E.O., Ward, M.K., Raney, D.E. 1954. Two simple media for the demonstration of payociamin and fluorescein. J. Lab. Clin. Med., 44: 301307.

Kneifel, W., Ulberth, F. and Schaffer, E. 1992. Tristymulus colour reflectance measurement of milk and dairy products. Lait. 72: 383-391.
Kumar, A., 2005. Environment \& Agriculture. APH Publishing, pp. 65.

Letham, D.S. 1971. Pl.Physiol. 25, pp. 391396.

Levine, M. 1918. Differentiation of B. coli and $B$. aerogenes on a simplified eosinmethylene blue agar. J Infect Dis. 23: 43-47.

Martin, J. P. 1950. Use of acid, rose bengal, and streptomycin in the plate method for estimation soil fungi. Soil Sci. 69: 215-232.

Massoumi, A. and Cornfield, A. H. 1963. A rapid method for determining sulphate in water extracts of soils. The Analyst. 88: 321-322.

Min, D. B. And Boff, J. M. 2002. Chemistry and reaction of singlet oxygen in foods. Compr. Rev. Food. Sci. Food Safety. 1: 58-72.

Natarajan, K. 2008. Panchagavya: A Manual (2nd Ed.). Organic Farming Association of India (OFAI), Mapusa, Goa, 56p.

Parvathi, S. U and Ushakumari K. 2017. Preparation and characterization of onfarm liquid organic manures, Trends in Biosciences, Volume 10(32):6880-6885.

Pathak, R. K. and Ram, R. A. 2013. Bioenhancers: A potential tool to improve soil fertility, plant health in organic production of horticultural crops. Progress. Hortic. 45(2): 237-254.

Ram, R. A., Singha, A., Vaish, S. 2017. Microbial characterization of on-farm produced bio-enhancers used in organic farming. Indian Journal of Agricultural Sciences, 88(1): 35-40.

Ravindra, U., Nayaka, M. K. And Revanna, M. L. 2016. Microbial quality evaluation of Liquid Jaggery. International Journal of Applied and Pure Science and Agriculture. Volume 2:114-117. Issue 6.

Sadasivam, S. and Manickam, A. 1996. Biochemical Methods for Agricultural 
Sciences. Wiley Eastern Ltd., New Delhi, 246p.

Sarkar, S., Kundu, S. S. and Ghorai, D., 2014. Validiation of ancient liquid organics: Panchagavya and Kunapajala as plant growth promoters. Indian J. Tradtnl. Knowledge, 13(2): 398-403.

Shankaran, D. 2009. Zero Budget Natural Agriculture. Keerthi Prakasana, Siddalinga Nagar, Gadang, pp9-12.

Singh, H. and Creamer, L. K. 1992. Heat stability of milk. In: Fox P. F., editor. Advanced Dairy Chemistry Proteins, Elsevier Science Publishers Ltd. Cambrige, pp. 621-656.

Sugumaran, P. and Janartham, B. 2007. Solubilization of potassium minerals by bacteria and their effect on plant growth. World Journal of Agricultural Sciences. 3(3): 350-355.

Sundara Rao, W. V. B., Sinha, M. K. 1963. Phosphate dissolving organisms in the soil and the rhizosphere. Indian J. Agr. Sci. 33: $272 \pm 278$.

Tyagi, A.K., Tripathi, M.K. and Karim, S.A., 1997. Effect of soaking on glucosinolate of mustard cake and its utilization in sheep feeding. Indian J. Anim. Sci., 67: 76-77.

Walkley, A. and Black, I.A. 1934. An examination of the Degtjareff method for determining soil organic matter and a proposed modification of the chromic acid titration method. Soil Sci. 39: 2938.

\section{How to cite this article:}

Bishal Chakraborty and Indrajit Sarkar. 2019. Quality Analysis and Characterization of Panchagavya, Jeevumrutha and Sasyamrutha. Int.J.Curr.Microbiol.App.Sci. 8(05): 2018-2026. doi: https://doi.org/10.20546/ijcmas.2019.805.234 